\title{
FORMULATION AND EFFECTIVITY TEST OF DEODORANT FROM ACTIVATED CHARCOAL OF PALM SHELL AS EXCESSIVE SWEAT ADSORBENT ON BODY
}

\author{
UCE LESTARI ${ }^{1 *}$, FAIZAR FARID ${ }^{2}$, AHMAD FUDHOLI ${ }^{3}$ \\ ${ }^{1}$ Pharmaceutical Study Program, Faculty of Science and Technology University of Jambi, Jambi, Indonesia. ${ }^{2} \mathrm{Chemical} \mathrm{Study} \mathrm{Program,}$ \\ Faculty of Science and Technology University of Jambi, Jambi, Indonesia. ${ }^{3}$ Department of Physics Engineering, Solar Energy Research \\ Institute, Universiti Kebangsaan Malaysia, 43600 Bangi Selangor, Malaysia. Email: ucelestari@unja.ac.id
}

Received: 08 April 2019, Revised and Accepted: 23 August 2019

ABSTRACT

Objective: The objective of this study was to know the physically stable deodorant preparations during storage and to obtain the preparations.

Methods: The evaluation of the physical properties of deodorant include: Organoleptic test, homogeneity, pH measurement, viscosity, flow properties, drying time, moisture content, flow time, density, cycling test, hedonic test, irritation test, and effectivity test of sweat adsorption. Activated charcoal used by the formulation of deodorant powder and roll on each with a concentration of $15 \%$.

Results: The physicochemical evaluation was obtained. Descriptively produced data stated that deodorant powder is more physically stable that deodorant roll-on which has separated during storage.

Conclusion: For the effectivity of sweat adsorption, deodorant powder is more effective than deodorant roll-on.

Keywords: Deodorant, Activated charcoal, Palm shell, Sweat.

(C) 2019 The Authors. Published by Innovare Academic Sciences Pvt Ltd. This is an open access article under the CC BY license (http://creativecommons. org/licenses/by/4. 0/) DOI: http://dx.doi.org/10.22159/ajpcr.2019.v12i10.33490

\section{INTRODUCTION}

Palm oil is a vegetable oil that has many types of minor components such as carotenoids which have the potential as a source of natural provitamin A and can replace the source of synthetic Vitamin A which is relatively expensive [1]. Indonesia and Malaysia are the two largest producer of palm oil in the worlds. Palm oil is one of the world's most rapidly expanding equatorial crops. Palm oil is extracted from oil palm fruits in the mills. The waste products of oil palm mills are empty fruit bunches, fibers, shells, and fronds. The high potential of palm oil in Indonesia, palm oil can be used as a product in the cosmetics industry [2,3]. The cosmetic industries are massive, exclusively consumer-based business with the market value of about $\$ 11.7$ billion as on 2016. Cosmetics are used to improve the physical appearance and prevent the natural processes that influence the exterior look of the human being, primarily, and used against the aging process. Several cosmetic products claim that they have appropriate positive effects on the skin such as anti-aging and skin tightening [4]. Today, many cosmetic industries produce various kinds of beauty products to care and increase confidence from the dangers of excessive sweating that cause body odor, one of them is deodorant

Deodorant is one of cosmetic preparations that consist materials or mixtures of materials that can be used to eliminate or reduce body odor as a result from excessive sweating and decomposition of sweat by bacteria. In general, deodorant can be liquid, such as roll-on and shaped powder such as sprinkle powder [5]. Sprinkle powder is able to absorb excessive sweat without leave marks on the clothes because the color of the powder, although the texture is ancient but it still much in demand, especially for those who have excessive sweating problems [6].

Activated charcoal was proven to be able to remove dirt on face and adsorb toxins and excessive sweat on the body. It is caused by oxygen content in carbon. Effectivity of activated charcoal of palm shell (Elaeis guineensis Jacg.) is better than the activated charcoal is used as beauty products [7]. One of them is deodorant either in powder and roll-on from that used to adsorb excessive sweats in the body that interfere daily activity and lower confidence [8].

\section{METHODS}

\section{Research material}

The material used in this research is the palm shell from PT Sumbertama Nusa Pertiwi, it is where the crude palm oil processing. The shell is widely available in the factory and still not widely utilized. The material used for deodorant powder and roll-on is activated charcoal, sodium stearate, gliserolum, alcohol, oleum rosae, aquadest, talkum, asam benzoat, and magnesium karbonat dan setil alcohol.

\section{Research tool}

Furnace, Ball Milling, sieve 200 mesh, digital scales, mortar dan stamper, porselen cup, beaker glass, stirring bar, measuring cup, water bath, thermometer, watch glass, viscometer Brookfield, Petri dish, picnometer, and $\mathrm{pH}$ meter were used.

\section{Sampling and processing of samples}

$10 \mathrm{~kg}$ of palms shell separated from the kernel, clean, and wash with running water then dry it in direct sunlight to dry perfectly until it have a constant weight [9].

\section{Process to make active charcoal}

Dry palms shell are carbonated in the furnace at $500^{\circ} \mathrm{C}$ for $30 \mathrm{~min}$ until it turns into charcoal. The carbonated charcoals are grinded using a grinder, it sieved with a 200 mesh sieve to obtain the same grain size and the final result is a charcoal powder. The charcoal powder is activated using a furnace for $2 \mathrm{~h}$ with a temperature of $600^{\circ} \mathrm{C}$, so an active charcoal of palms shell is ready to use [10].

Determination of active charcoal absorption quantitatively to iodine

Dry samples of $0.25 \mathrm{~g}$ were put into Erlenmeyer, then $25 \mathrm{ml} \mathrm{ofI}_{2} 0.1 \mathrm{~N}$ solution was added, then shaked for $15 \mathrm{~min}$ at room temperature and 
then filtered. The filtrate of $10 \mathrm{ml}$ was titrated with $0.1 \mathrm{~N}$ sodium thiosulfate $\left(\mathrm{Na}_{2} \mathrm{~S}_{2} \mathrm{O}_{3}\right)$ solution until light yellow and then given a few drops of $1 \%$ starch solution and the titration was continued until the color disappeared exact. Iodine absorption can be determined by the following equation [11].

$$
\mathrm{SI}=\frac{\text { Ml sample }-\mathrm{T} \frac{\mathrm{C} 1}{\mathrm{C} 2} \times \mathrm{W} 1 \times \mathrm{Fp}}{\mathrm{g} \mathrm{sample}}
$$

which:

DSI = Iodin absorption $(\mathrm{mg} / \mathrm{g})$

Ml sample $=$ Filtrate titrated $(10 \mathrm{ml})$

$\mathrm{T}=$ Titration volume $\mathrm{Na}_{2} \mathrm{~S}_{2} \mathrm{O}_{3}(\mathrm{ml})$

$\mathrm{C} 1$ = Concentration $\mathrm{Na}_{2} \mathrm{~S}_{2} \mathrm{O}_{3}(\mathrm{~N})$

$\mathrm{C} 2$ = Concentration iodine $(\mathrm{N})$

$\mathrm{WI}=$ Weighted $(12.693 \mathrm{mg} / \mathrm{ml})$

$\mathrm{Fp}=$ Dilution factor $(2.5)$

Design formula deodorant roll-on and powder activated charcoal palm shell

Formula deodorant roll-on and powder activated charcoal palm shell are shown in Table 1.

\section{Manufacture of deodorant roll-on}

Sodium stearate, glycerol, and alcohol are mixed into a beaker glass. Heated above the water bath at a temperature of $<80^{\circ} \mathrm{C}$. Overheating will cause alcohol more evaporate. During heating stirred continuously so that the ingredients are dissolved in alcohol and added the activated charcoal little by little until all mixed completely. After the ingredients are dissolved in alcohol and the mass is mixed, down from the fire. Left a few moments then add aqua rosae into it. Insert it into the container.

\section{Manufacture of loose powder deodorant}

Dissolve cetyl alcohol in a certain amount of alcohol and add it to all the ingredients (partially talum, magnesium carbonate, and benzoic acid) referred to as period 1. Oleum rosae is mixed into the rest of the talum, if it is evenly introduced into period one and add the activated charcoal gradually. Then, all the time sieved with sieve no 150

Physical character evaluation of roll-on and loose powder deodorant

Table 2 shows the evaluation of the physical properties of deodorant include: Organoleptic test, homogeneity, $\mathrm{pH}$ measurement, viscosity, flow properties, Hausner Factor, drying time, moisture content, flow time, flow rate, specific weight (SW), cycling test, hedonic test and irritation test, and effectiveness test absorption of sweat.

\section{RESULTS AND DISCUSSION}

Determination of active charcoal absorption quantitatively to iodine

The parameter that can show the quality of the activated charcoal is the adsorption power to the iodine solution. The larger the number of iodine the greater the ability of solute. Therefore, the absorption capacity of iodine is an important indicator in assessing activated charcoal. The

Table 1: Formula deodorant roll-on and powder activated charcoal palm shell

\begin{tabular}{ll}
\hline Deodorant roll-on & Deodorant powder \\
\hline Activated charcoal palm shell & Activated charcoal palm shell $15 \%$ \\
$15 \mathrm{~g}$ & \\
Sodium stearate $20 \mathrm{~g}$ & Talcum $69.5 \%$ \\
Gliserolum $20 \mathrm{ml}$ & Asam benzoate $3 \%$ \\
Alcohol $75 \mathrm{ml}$ & Magnesium karbonat $12 \%$ \\
Aqua rosae ad $100 \mathrm{~g}$ & Setil alcohol $0.5 \%$ \\
- & Oleum rosae ad $100 \mathrm{~g}$ \\
\hline
\end{tabular}

absorption capacity of iodine shows the ability of activated charcoal to absorb substances with molecular sizes smaller than $10 \dot{A}$ or give an indication of the number of pores with a diameter of $10-15 \dot{A}$.

The aim of this test is to know the ability of activated charcoal to absorb the colored solution. The result of the analysis of iodine absorption power resulting from the size of the active charcoal particles of activated charcoal particles of coconut shell is $766.443 \mathrm{mg} / \mathrm{g}$ so that the absorption of activated charcoal oil palm shell has absorptive capacity that already meets the Indonesian National Standard [18] of more than $750 \mathrm{mg} / \mathrm{g}$

\section{Organoleptic test}

Organoleptic determination of a product is an appraisal by means of the sense apparatus of the sense of sight, the sense of taste, and the sense of smell. In this determination, the color of each deodorant of the roll-on shape and the powder of the saved syringe from the $1^{\text {st }}$ week to $4^{\text {th }}$ week is relatively stable no change in color, aroma, shape, and consistency during storage.

\section{Homogeneity test}

The homogeneity of powder deodorant is more homogeneous than rollon deodorant because of its separated if it is kept at room temperature during the $1^{\text {st }}$ week until the $4^{\text {th }}$ week during storage, while after heating with water bath at $80^{\circ} \mathrm{C}$ gives homogenous preparation.

\section{pH test}

Underarm skin has a $\mathrm{pH}$ different from the $\mathrm{pH}$ of skin physiology in general where the physiological $\mathrm{pH}$ of the skin is about 4.5-6.5 while the $\mathrm{pH}$ of the underarm skin is 4-6.8 [13]. The results of $\mathrm{pH}$ examination of roll form deodorant preparation as measured by $\mathrm{pH}$ meter equipment still included in the $\mathrm{pH}$ of underarm skin is 6.51. Examination of $\mathrm{pH}$ during storage at room temperature, temperature $40^{\circ} \mathrm{C}$ and temperature of $4^{\circ} \mathrm{C}$ decreased that the $\mathrm{pH}$ is not significant but still in the range of skin underarm $\mathrm{pH}$.

\section{Viscosity and flow properties test}

Viscosity is a statement of resistance of a liquid to flow, the higher the viscosity the greater the resistance [19]. Viscosity was measured using a Brookfield viscometer with spindle 2 in RPM 100. The result of deodorant roll form viscosity was 0.651 Pa.s $(651 \mathrm{cps})$ with plastic flow properties since the preparation was included in the non-newton liquid. The viscosity of the non-newton liquid with the plastic flow properties of the deodorant preparation has a range between 0.25584 and 3.19452 Pa.s (255.84-3194.52 cps). The higher the viscous the dosage will be, the more dilute. Percent compressibility (\% C) of deodorant powder of $23.84 \%$ which means the dosage has bad flow properties (\% C 23-25\%) influenced by the amount of air congestion (porosity) owned by powder of $99.39 \%$ and powder the preparation has voluminous properties and the powder has no moisture content with $\%$ moist content (MC) of $0 \%$.

The flow property of powder is affected by several factors, namely, SW, porosity, particle shape, and moisture content. Good flow properties make it easy to pour easily from the container so that the uniformity of weights can be well preserved [20].

\section{Flow rate properties test}

Flow velocity influenced moist deodorant content of powder with $0 \%$ $\mathrm{MC}$ has a flow rate of $0.296 \mathrm{~g} / \mathrm{s}$. This is because the cohesiveness between the powders is greater than the force of gravity so that the powder is difficult to flow. Dry powder has a small friction with the container wall so it is easy to flow freely, based on the above that drying will improve the powder flow, but dry powder will actually decrease the flow rate because it produces many fines that can inhibit the flow of powder.

\section{Drying time test}

The drying time test is carried out by observing the time it takes for the preparation to dry, i.e. the time from which deodorant roll-on begins 
Table 2: Evaluation of the physical properties recapitulation of deodorant roll-on and powder

\begin{tabular}{|c|c|c|c|}
\hline Category & Deodorant roll on & Deodorant powder & Parameter \\
\hline Organoleptic & $\begin{array}{l}\text { Black, aroma of rosae, liquid and } \\
\text { half solid consistency, the sensation } \\
\text { of coldness*) }\end{array}$ & $\begin{array}{l}\text { Grey, aroma of rosae, very fine } \\
\text { powder*) }\end{array}$ & Stable no change of color, odor, shape [12] \\
\hline Homogeneity & $\begin{array}{l}\text { Homogeneous, if silenced there is } \\
\text { separation }\end{array}$ & Homogeneous*) & Homogeneous [12] \\
\hline $\mathrm{pH}$ & $\left.6.51^{*}\right)$ & - & Deodorant roll on: pH 4-6.8 [13] \\
\hline Viscosity & 0.651 Pa.s $\left.(651 \mathrm{cps})^{*}\right)$ & - & $\begin{array}{l}\text { Deodorant roll on: } 0.25584-3.19452 \text { Pa.s } \\
(255.84-3194.52 \mathrm{cps})\end{array}$ \\
\hline Rheology & Plastis*) & Bad flow properties (\% C: $23.84 \%$ & $\begin{array}{l}\text { Deodorant roll-on: Non newton liquid } \\
\text { has rheology plastis, pseudoplastis dan } \\
\text { dilatan[14] } \\
\text { Deodorant powder: \% C 5-15\%, very } \\
\text { good } \\
\% \text { C } 12-16 \% \text {, good } \\
\% \text { C } 18-21 \% \text {, pretty good } \\
\% \text { C } 23-25 \% \text {, bad } \\
\% \text { C } 33-38 \% \text {, very bad } \\
\% \text { C }>40 \% \text {, very badly [14] }\end{array}$ \\
\hline Hausner Factor (HF) & - & 0.762 & $\begin{array}{l}\mathrm{HF}<1.25: \text { Good } \\
\mathrm{HF}>1.5: \text { Bad }[14]\end{array}$ \\
\hline Flow time & - & $135 \mathrm{~s}$ & $\begin{array}{l}\text { Deodorant powder: Every } 40 \mathrm{~g} \text { of powder } \\
\text { cannot be more than } 4 \mathrm{~s} \text { [14] }\end{array}$ \\
\hline Flow rate & - & $0.296 \mathrm{~g} / \mathrm{s}$ & $\begin{array}{l}\text { Deodorant powder; every } 40 \mathrm{~g} \text { of powder } \\
\text { cannot be more than } 4 \mathrm{~g} / \mathrm{s} \text { [15] }\end{array}$ \\
\hline Drying time & $\left.15 s^{*}\right)$ & - & Cannot be more than $15-30 \min [14]$ \\
\hline Moisture content & - & $0 \%$ & $2-4 \%[15]$ \\
\hline SW & $\left.1.0209 \mathrm{~g} / \mathrm{ml}^{*}\right)$ & $\begin{array}{l}\text { SW true: } 0.3773 \mathrm{~g} / \mathrm{ml} \\
\text { SW real: } 0.476 \mathrm{~g} / \mathrm{ml} \\
\text { SW incompressible: } 0.625 \mathrm{~g} / \mathrm{ml}\end{array}$ & $\begin{array}{l}\text { Deodorant roll on: }>1 \mathrm{~g} / \mathrm{ml} \text { (for heavier } \\
\text { preparations of water) } \\
\text { Deodorant powder }[16]:<1 \mathrm{~g} / \mathrm{ml} \text { (for a } \\
\text { lighter preparations of water) }\end{array}$ \\
\hline $\begin{array}{l}\text { Cycling test } \\
\text { Organoleptic dan } \\
\text { homogeneity }\end{array}$ & $\begin{array}{l}\text { Black, aroma of rosae, liquid and } \\
\text { half solid consistency, the sensation } \\
\text { of coldness and homogeneous*) }\end{array}$ & $\begin{array}{l}\text { Gray, aroma of rosae, very fine } \\
\text { powder and homogeneous*) }\end{array}$ & $\begin{array}{l}\text { Stable no change of color, odor, shape[12] } \\
\text { Homogeneous [12] }\end{array}$ \\
\hline Temperature $40^{\circ} \mathrm{C}$ & $\mathrm{F}=0.5$ & & \\
\hline Temperature $4^{\circ} \mathrm{C}$ & $\left.\mathrm{F}=1^{*}\right)$ & & \\
\hline $\mathrm{pH} 25^{\circ} \mathrm{C}$ & 6.04 & - & Deodorant roll on: pH 4-6.8 [13] \\
\hline $\mathrm{pH} 40^{\circ} \mathrm{C}$ & 6.30 & & \\
\hline $\mathrm{pH} 4^{\circ} \mathrm{C}$ & $\left.5.24^{*}\right)$ & & \\
\hline Hedonic test & $\begin{array}{l}\text { Like }(100 \%) \text { because the sensation } \\
\text { of coldness, uncomfortable in use } \\
\text { for leaving marks or black spots*) }\end{array}$ & $\begin{array}{l}\text { Do not like }(100 \%) \text { ordinary } \\
\text { sensation but comfortable on use } \\
\text { because it does not leave marks or } \\
\text { black spots }\end{array}$ & $\begin{array}{l}10 \text { panelist very like (4), rather like ( } 3 \text { ), } \\
\text { do not like much ( } 2 \text { ) and do not like very } \\
\text { much (1) }\end{array}$ \\
\hline Irritation test & Negative $100 \%$ no reaction*) & $\begin{array}{l}\text { Negative } 90 \% \text { (no reaction and } \\
\text { skin flushed }(+) 10 \%\end{array}$ & $\begin{array}{l}\text { No reaction }(-) \text {, skin flushed }(+) \\
\text { skin flushed and itchy }(++) \text {, skin } \\
\text { swell }(+++)[14,17]\end{array}$ \\
\hline $\begin{array}{l}\text { Effectiveness test } \\
\text { absorption of sweat }\end{array}$ & & & $\begin{array}{l}<33 \% \text { (very dry skin), } 34-37 \% \text { (dry skin), } \\
38-42 \% \text { (normal skin), } 43-46 \%\end{array}$ \\
\hline Before sweating & $54.45 \%$ & $53.77 \%$ & (moist skin) \\
\hline After sweating & $62.70 \%$ & $61.74 \%$ & $\begin{array}{l}\text { "After the use of deodorant moisture } \\
\text { content to the current value before } \\
\text { sweating" }\end{array}$ \\
\hline After use & $58.81 \%$ & $52.38 \% *$ ) & \\
\hline
\end{tabular}

\% C: Percent compressibility, SW: Specific weight

to be applied to the skin until a dry layer is completely formed. The requirement for the mongering dosage time is 15-30 min [21], where deodorant drying time rolls on for $15 \mathrm{~s}$ which dries faster because it contains alcohol.

\section{Determination of SW}

SW is the weight ratio of material with water at the same volume and temperature using a piknometer. SW measurements were performed to determine the addition of SW to storage each week, where deodorant roll-on had a SW of $1.0209 \mathrm{~g} / \mathrm{ml}$ specifically for heavier preparations of water having SW >1 g/ml [16], whereas deodorant powder has SW True:
$0.3773 \mathrm{~g} / \mathrm{ml}$, SW real: $0.476 \mathrm{~g} / \mathrm{ml}$, and SW compression: $0.625 \mathrm{~g} / \mathrm{ml}$ because the powder is voluminous with lighter $\mathrm{SW}(<1 \mathrm{~g} / \mathrm{ml})$.

\section{Sedimentation degrees test}

Sedimentation is one-way of separation between components or particles based on their density differences through a flow medium. The roll form of deodorant preparation during stability test of the preparation by cycling test method during storage at room temperature, the heat temperature separated at the price of $\mathrm{F}=0.5$, it is said unstable preparation whereas at cold temperatures it does not experience separation with the price $\mathrm{F}=1$, when $\mathrm{F}=1$ is expressed as a 


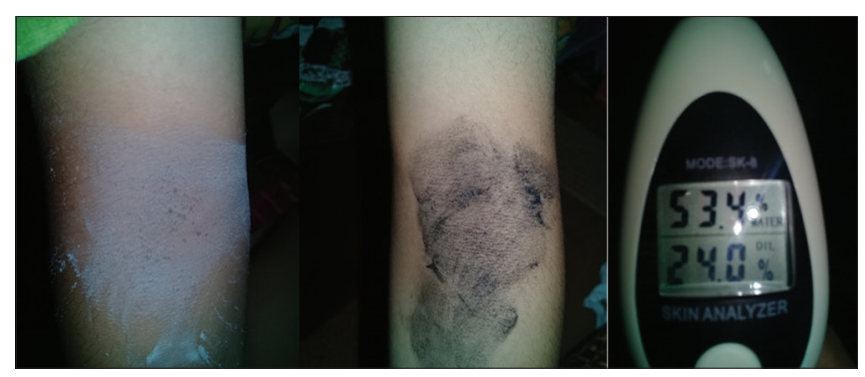

Fig. 1: The effectiveness of sweat absorption test

good preparation because of the absence of a clear supernatant at the embankment.

\section{Hedonic test}

This test is done to see consumer preferences in terms of color, smell, and sensation of comfort when worn on the skin, and the potential of deodorant in causing itching and redness of the skin after applied for 5 min. The panelist population used was 10 people consisting of women and men. From the results obtained that panelist likes $(100 \%)$ for deodorant roll form, because there is a cold sensation but uncomfortable in use because it leaves marks or black spots, while dislikes $(100 \%)$ for deodorant form of powder sow where the sensation is normal but comfortable on use because it does not leave marks or stains.

\section{Irritation test}

Panelist irritation test includes human with sex of woman and man who is physically healthy, has no history of allergy or disease, which is closely related to allergic reaction and has expressed its willingness as panelist. The observed reactions are typical allergies in the test area, i.e., the forearm or wrist folds with reddish skin symptoms, itching, and swollen skin. From 10 panelists for deodorant roll form with 10 negatives $(100 \%)$ result with reaction observed no reaction while deodorant powder form with 9 negatives (90\%) with reaction observed no reaction and one positive person $(10 \%)$ with a diuretic reaction is difficult to blush.

\section{The effectiveness of sweat absorption test}

Fig. 1 shows testing effectiveness of the absorption of sweat using skin analyzer tool that shows the value of water content on the skin. The water content of 10 panelists first checked before the activity to produce sweat and then the water content is recorded, after that the panelist must be active to produce sweat before applied deodorant. From the results of 10 panelist that the effectiveness test after the administration of deodorant roll on against the absorption of excess sweat gives a decrease in water content by $3.89 \%$ while the effectiveness test after the administration of deodorant powder on absorption Excessive sweating has decreased by $9.36 \%$ based on the preparation of deodorant powder is more effective than the deodorant roll on.

\section{CONCLUSION}

From descriptively produced data, it shows that loose powder deodorant is more stable during storage than roll-on deodorant which separated during storage, although roll-on deodorant has the best physical properties than the powder. For the effectiveness of the absorption of sweat, deodorant powder is more effective than deodorant roll-on.

\section{ACKNOWLEDGMENT}

The authors would like to thank the integrated laboratory related and LPPM to University Jambi and PT Sumbertama Nusa Pertiwi.

\section{AUTHORS' CONTRIBUTIONS}

The idea of the research was suggested by Uce Lestari, along with literature collection, manuscript writing, editing, and data calculations. The materials preparation and laboratory experiments work were carried out by Faizar Faridwith the participation of Uce Lestari. The manuscript revision was done by Dr. Ahmad Fudholi.

\section{CONFLICTS OF INTEREST}

The authors declare that they have no conflicts of interest.

\section{REFERENCES}

1. Sari F, Sinaga KR, Siahaan D. Formulation and evaluation of red palm oleinnanoemulsion. Asian J Pharm Clin Res 2018;11:237-40.

2. Fudholi A, Sopian K, Alghoul MA, Ruslan MH, Othman MY. Performances and improvement potential of solar drying system for palm oil fronds. Renew Energy 2015;78:561-5.

3. Fudholi A, Ruslan MH, Othman MY, Azmi MS, Zaharim A, Sopian K. Drying of palm oil fronds in solar dryer with finned double-pass solar collectors. WSEAS Trans Heat Mass Transf 2012;7:105-14.

4. Chaiyasut C, Kesika P, Sakdakampanat P, Peerajan S, Sivamaruthi BS. Formulation and evaluation of stability of Thai purple rice bran-based cosmetic products. Asian J Pharm Clin Res 2018;11:99-104.

5. Mitsui T. New Cosmetic Science. $1^{\text {st }}$ ed. Amsterdam: Elsevier; 1997.

6. Harry RG. Harry's Cosmeticology. $7^{\text {th }}$ ed. New York: Chemical Publishing Company Inc.; 1982.

7. Hendra D, Pari G. Making of activated charcoal from empty palm oil bunches. Bull Forest Prod Res 1999;17:133-22.

8. Harry RG. Harry Cosmeticology. New York: Chemical Publishing; 2000.

9. Lestari U, Farid F, Sari PM. Formulasi dan uji sifat fisik lulur body scrub arang aktif dari cangkang kelapa sawit sebagai detoksifikasi. J Sains Teknol 2017;19:74-9.

10. Salim SS. Tecnical Guidanceon Making Activated Charcoal. Center for Research and Development of Forest Products and Socio-Economic Environment; 1994.

11. ASTM Standards, ASTM D3702-94. Standart Test Method for Wear Rate Coefficient of Materials in Self Lubricated Rubbing Contact Using Athrust Washer Testing Machine. United States: ASTM International; 1999.

12. Rowe RC, Sheskey PJ, Owen S. Handbook of Pharmaceutical Excipients. $5^{\text {th }}$ ed. London: Pharmaceutical Press; 2009.

13. Stawiski MA. Pathophysiology of Structure and Function of the Skin. $4^{\text {th }}$ ed. Jakarta: EG; 1994.

14. Voight R. Buku Pelajaran Teknologi Farmasi. Yogyakarta: Gadjah Mada University Press; 1994.

15. Lachman L. Theory and Practice of Industrial Pharmacy. Jakarta: University of Indonesia; 1994.

16. Ansel CH. Pharmaceutical Calculation. Jakarta: Book Publisher of Medicine, EGC; 2006.

17. Depkes RI. Formularium Cosmetika Indonesia. Jakarta: Departement of Health Republik Indonesian; 1985.

18. Depkes RI. Farmacopea Indonesian. $4^{\text {th }}$ ed. Jakarta: Departement of Health Republik Indonesian; 1995.

19. Martin A, Swarbrick J, Cammarata A. Pharmaceutical Basic Physics of Chemistry in Pharmaceutical Sciences. Jakarta: University of Indonesia Press; 2008 .

20. Martin A. Pharmaceutical Physics. Jakarta: University of Indonesia; 1990.

21. Stephen SC, Paul ZA, Crotty IM, Andrew B. Cosmetic Strips with Liquid Crystal Temperature Dependent Color Change, US Patent, No. 6,270,783. Assigned to Unilever Home and Personel Care. USA: Division of Conopco, Inc.; 2001. 